\title{
The Archaeology of Europe's Drowned Landscapes: Introduction and Overview
}

\author{
Geoff Bailey, Nena Galanidou, Hans Peeters, \\ Hauke Jöns, and Moritz Mennenga
}

\begin{abstract}
This is the final volume of the SPLASHCOS research network and marks the completion of an international and collaborative survey to compile and evaluate the known records of underwater material around Europe's coastlines, deposited during periods of low sea level and subsequently drowned by sea-level rise at the end of the Last Glacial Period. Some of these underwater finds, especially those exposed in the intertidal zone, have been known about since the last century but have languished in obscure publications, museum archives, or national sites and monument records. Systematic underwater investigation
\end{abstract}

G. Bailey $(\triangle)$

Department of Archaeology, University of York, York, UK

College of Humanities, Arts and Social Sciences, Flinders University, Adelaide, SA, Australia e-mail: geoff.bailey@york.ac.uk

N. Galanidou

Department of History and Archaeology, University of Crete, Rethymno, Greece

e-mail: galanidou@uoc.gr

H. Peeters

Groningen Institute of Archaeology, University of Groningen, Groningen, The Netherlands

e-mail: j.h.m.peeters@rug.nl

H. Jöns · M. Mennenga

Lower Saxony Institute for Historical Coastal

Research, Wilhelmshaven, Germany

e-mail: joens@nihk.de; mennenga@nihk.de and excavation did not begin until the 1970s and only then in a few research centres, notably in Denmark, Bulgaria, and Israel. Only since the turn of the new millennium has this field of underwater research come into focus as a significant missing part of the archaeological record, and many new investigations have begun or gained new momentum during the past decade, not least because of improved technologies of marine exploration and remote sensing, intensified industrial exploitation of the seabed, and collaboration between offshore industries, government agencies, and commercial archaeologists. The material reviewed here covers 20 countries bordering all the major marine basins from the Atlantic coasts of Ireland and Norway to the Black Sea and from the western Baltic to the eastern Mediterranean. Nearly 3000 underwater find spots are known, ranging from isolated artefacts to in situ settlements and spanning a period from c. 1 million years ago to the establishment of modern sea level between 7000 and 2000 years ago. In this introductory chapter, we outline the history of investigations, highlight the importance of this underwater record for a better understanding of European (and world) prehistory, explain the rationale for the research and the way we have structured the volume, and summarise some key issues. The chapters are organised in four parts, and each part is prefaced by its own 
editorial introduction summarising key themes for that group of chapters.

\section{Keywords}

Sea-level change $\cdot$ Submerged landscapes · Underwater archaeology $\cdot$ Cultural heritage · Stone Age

\subsection{Background}

It has been well understood for many decades that sea level has been much lower than the present for most of human history over the past one million years and more, repeatedly reaching to a depth of more than $100 \mathrm{~m}$ below present sea level and making extensive areas of land available for human settlement and dispersal over many millennia. In Europe, the amount of new land exposed at lowest sea level during the Last Glacial Maximum 20,000 years ago has been estimated at c. 2.5 million $\mathrm{km}^{2}$, representing some $40 \%$ of the present-day land mass (Fig. 1.1). ${ }^{1}$ Much of this submerged territory was well-watered and well-stocked with plants and animals, often providing more attractive environments for human exploitation than the contemporaneous hinterlands and arguably, in some cases, environments with no known modern analogue (Bailey and Flemming 2008). Nearly all this land was progressively lost to sea-level rise over a period of about ten millennia as the continental ice sheets melted, creating an ever-changing mosaic of palaeogeographic and palaeoenvironmental conditions until sea-level rise reached the modern position.

Archaeologists, however, have for a long time been reluctant to focus on this missing record or to do anything about it. In part this stems from a belief that nothing of much significance could have survived the destructive impact of inunda-

\footnotetext{
${ }^{1}$ These are very approximate figures and are based on a land area that largely excludes European Russia. The total area given here is lower than the 4 million $\mathrm{km}^{2}$ cited in Flemming et al. (2017a, p.1), because the latter figure was arrived at by taking $40 \%$ of the current European land mass including European Russia.
}

tion and that whatever has survived would in any case make little difference to our understanding of world prehistory. Other factors are the perceived difficulties and costs of mounting research expeditions to search for whatever minimal remains might still be found on or beneath the seabed and the high risk of failure. A further disincentive is the deep-rooted belief that the seashore and the sea beyond were, at best, of marginal significance to the main trajectories of human evolution and social development until a very late period in recent millennia and that all the major social, economic, and technological transformations that created the foundations of early civilisation were largely driven by the exploitation of terrestrial resources on dry landscavenging, hunting, plant gathering, domestication of plants and animals, and village farming (Erlandson 2001; Bailey and Milner 2002). Typically, this belief provides a rationalisation for not engaging with underwater research, and that lack of engagement in its turn reinforces existing preconceptions, creating a perpetual and self-reinforcing circularity of argument that can stifle new research initiatives.

Four factors have gradually brought about a change in the climate of opinion (for overviews and recent discussion, see Flemming 2004; Benjamin et al. 2011, 2017; Evans et al. 2014; Harff et al. 2016, 2017a; Bailey et al. 2017; Flemming et al. 2014, 2017a; Fischer and Pedersen 2018; Sturt et al. 2018; Wickham-Jones 2018).

1. The steady accumulation of underwater finds in many parts of the world demonstrating that a great deal of prehistoric material, including palaeontological remains of Ice Age mammals as well as archaeological finds, has survived on the seabed, some of it with preservation of organic materials, food remains, and items of material culture sealed beneath marine sediments in anaerobic sediments, items that rarely survive in archaeological deposits on the present-day land surface.

2. Better information about sea-level change, bathymetry and sea-bed morphology that has 


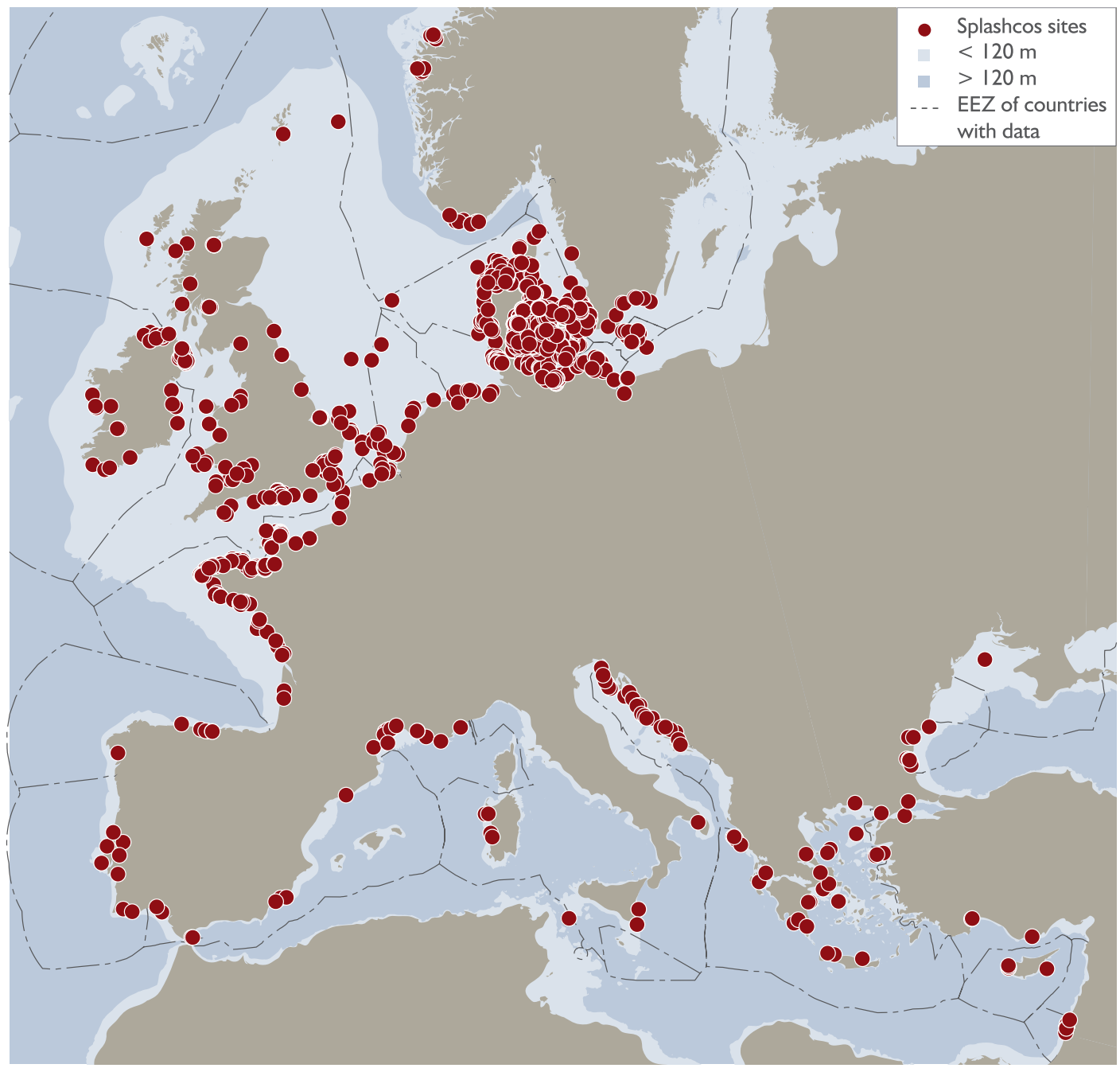

Fig. 1.1 Map of Europe showing the general distribution of known underwater settlements and find spots of the Stone Age or Early Bronze Age. The total number of recorded sites is 2640, and more detailed distribution maps can be found in the national overviews. The map also shows the $-120 \mathrm{~m}$ bathymetric contour (light blue shading), which gives a measure of the variable extent of the continental shelf in different regions, and the boundaries of the offshore Exclusive Economic Zones of each nation state. Site information from the SPLASHCOS Viewer http://splashcos-viewer.eu. For summary of site data, see Appendix I. Drawing by Moritz Mennenga

demonstrated more clearly the pattern of sealevel change, the length of time that low sea levels have persisted, and how much land has been lost since the Last Glacial Maximum. This is coupled with a growing realisation that this extensive terrestrial territory harboured concentrations of plant and animal life, water supplies, and human settlement, with major consequences for social, economic, and demographic change as land gradually sunk beneath the waves.

3. A growing imperative to study sea-level change, stimulated by the threat of global warming and sea-level rise in the coming centuries, and an interest in harnessing the extensive archives of palaeoenvironmental and archaeological information on the continental shelf to better understand the pattern and 
causes of past sea-level changes and their human impact.

4. Intensification of industrial and commercial exploitation of the seabed and the extension of government responsibilities, legislation, regulatory regimes, and international conventions to the protection of the underwater cultural heritage.

The research culminating in this volume has been carried out in parallel with two other closely related projects as part of the SPLASHCOS Action: a pan-European review of the geomorphology and palaeoenvironments of the continental shelf and the conditions affecting the preservation and discovery of prehistoric archaeological materials (Flemming et al. 2017a) and the compilation of a publicly available online database and maps with records of all known underwater finds of prehistoric archaeology in Europe-the SPLASHCOS Viewer (http:// splashcos-viewer.eu/; http://splashcos.maris2. $\mathrm{nl} /$ ). In Europe, the number of underwater Stone Age finds reported from different countries was already known to be many hundreds even before the SPLASHCOS Action began, and part of the stimulus to the project was to bring together the scattered reports of such finds into a single archive and to provide a fuller understanding of what is available and its wider significance.

The aim of this volume, then, is to provide, for the first time, a comprehensive description and evaluation of the currently known underwater archaeology on the submerged landscapes of the European continental shelf and the challenges facing future research. Our chronological and thematic focus is principally on sites that were originally located on dry land but were subsequently inundated by sea-level rise. In practice, this refers to Stone Age material before about 6000-5000 BP on most coastlines, but it includes Bronze Age or even Iron Age sites in those regions where metal technologies appeared early or relative sea level has continued to rise because of vertical land movements or continued melting of continental ice into the world oceans. We discuss issues of sea-level change and define and qualify our chronological and spatial boundaries in greater detail below.

Our aim in this chapter is to make some introductory comments about the following topics:

- The significance of Europe in its world context as a case study in the history of the continental shelf.

- The pattern and measurement of sea-level change and the uncertainties associated with it.

- The rationale for the way in which we have structured the volume and organised the chapters.

- The geographical and chronological scope of the work, including the definition of terms, their benefits and limitations, and the compilation of the SPLASHCOS Viewer.

- The variable conditions that have affected the preservation and discovery of underwater sites.

- Key research themes concerning human evolutionary and social developments that inform the volume as a whole.

\subsection{Europe as a Case Study}

The case for concentrating on the evidence of Europe's coastlines deserves some opening comment, given that Europe represents quite a small fraction of the world's land surface, and just one relatively limited regional record in the much larger panorama of world prehistory.

By convention, Europe as a geographical concept is usually taken to include all the territory west of the Ural Mountains and the Ural River, including the very large area of European Russia with coastlines on the Arctic Ocean and the Caspian Sea. In this volume we confine our attention to those coastal regions that border the Baltic Sea in the north, the Atlantic Ocean to the west, and the Black Sea and Mediterranean Sea to the south. In practice this excludes most of the western zone of the Russian Federaton (European Russia), apart from its short sections of coastline at the eastern end of the Baltic Sea and on the 
northern coastline of the Black Sea. We also include Turkey within these boundaries, though it has very few underwater finds, Cyprus, and Israel, which has a long history of underwater investigations and one of the most important and well-studied groups of underwater sites in the world. We do not include other countries bordering the eastern Mediterranean (Syria, Lebanon, Israel, and the Palestinian National Authority) nor all European countries with a coastal border (notable absences are Albania, BosniaHerzegovina, and Montenegro), because of lack of underwater investigation and absence of information.

From an archaeological point of view, one reason for focussing on Europe is the simple fact that it has one of the longest traditions of research on the prehistoric archaeology and submerged landscapes of the continental shelf anywhere in the world, extending back to the nineteenth century in some countries, and some of the largest currently known concentrations of prehistoric archaeological sites. This is especially the case in the western Baltic and to a lesser extent in the southern North Sea, the south-west corner of the Black Sea, and the eastern Mediterranean. Whether this concentration is the product of unusual conditions of site preservation and visibility peculiar to European and Mediterranean conditions, or rather to high levels of expert and public interest in these regions and sustained monitoring and investigation over many decades, is a question to be explored and is addressed in the relevant chapters of this volume.

Also, the long-term history of human occupation in Europe witnessed a number of developments that are of relevance to the some of the biggest themes in world prehistory. These include the earliest dispersal of our human ancestors into Europe at least one million years ago from a presumed centre of origin in Africa, most likely via the Levantine corridor but also very likely taking advantage of favourable territories for settlement and dispersal on now submerged landscapes especially in the Aegean region and possibly also involving sea crossings of the Mediterranean; early developments in the exploitation of marine foods, the resources of offshore islands, and sea- faring; the colonisation or recolonisation of extensive new territories exposed by the retreating ice; and the early development and dispersal of agricultural and metal-using societies including some of Europe's earliest complex stratified societies such as the Minoan civilisation on Crete and the Varna culture of Bulgaria. All of these developments were taking place at a time when sea levels were lower than present; many most likely had a coastal or maritime aspect; and it is likely that the investigation of the now-submerged coastal regions and palaoeshorelines of Europe and the Mediterranean will throw entirely new light on these developments and new information of interest and relevance at the world scale.

Moreover, the environments available for human occupation on Europe's submerged landscapes ranged from periglacial tundra in the north to Mediterranean woodland in the south and included dry lands, wetlands, lakes, rivers, estuaries, marshes, and coastlines with intertidal zones and offshore conditions ranging from shallow marshy shorelines and extensive mudflats to rocky shorelines in tideless basins, many of them subject to quite rapid and dramatic changes resulting from changes in sea level and the dynamic processes of geomorphological change at the coast margin. These would have offered great variety of opportunities to prehistoric societies as well as challenges to be overcome or succumbed to.

This is not to overlook the fact that traditions of underwater research, the discovery of underwater sites, and the investigation of their relevance to themes in the early development of human society have been going on in other parts of the world. Perhaps the largest concentration of research after Europe is in North America, especially on the coastlines of the Northwest Pacific and the Gulf of Florida, with more sporadic finds or new work only recently getting under way elsewhere and in other parts of the world (see in particular chapters in Masters and Flemming 1983; Benjamin et al. 2011; Evans et al. 2014; Harff et al. 2016; Bailey et al. 2017; Veth et al. 2019). Nevertheless, the concentration of finds, expertise, scientific research, and public interest in Europe is exceptional. 
There are other reasons why Europe offers unusual interest and opportunities for underwater research. Although it has a continental hinterland, Europe has a strongly maritime character with its many peninsulas and large offshore islands, its large semi-enclosed marine basins, its convoluted coastlines and archipelagos, and a very high ratio of coastline to land area, especially if one takes into account the many thousands of smaller offshore islands. It also has a great variety of coastal and offshore geomorphologies and oceanographic conditions within a relatively small area of the Earth's surface, especially as these affect the likely preservation and accessibility of submerged landscapes and archaeological materials. These conditions range from the virtually tideless basins of the Baltic, the Mediterranean, and the Black Sea, many of their coastlines with limited wind fetch or exposure to storms, to exposed coastlines facing the Atlantic Ocean and the North Sea in the west with very high tidal ranges.

Offshore, conditions range from shallow and extensive areas of continental shelf with high rates of sedimentation and coastal peat formations, as, for example, in the North Sea and the NW Black Sea, to narrow and rocky coastlines with steep drop offs and narrow shelves as in much of the Mediterranean. The Mediterranean, because of its unusual geological history and its extensive areas of limestone, has a unique karstic geomorphology of erosion and cave formation along many of its coastlines. The low sea-level stands of the Pleistocene accentuated cliff-bound shorelines and creation of coastal caves resulting from intensified groundwater movements and carbonate dissolution. These features are not unique to the Mediterranean but amplified earlier processes of erosion that took place during the Messinian salinity crisis between c. 5.96 and 5.33 million years ago, when the Mediterranean was cut off from the Atlantic and high rates of evaporation turned it into a deep and dry basin (Flemming and Antonioli 2017). This has resulted in thousands of coastal caves, many of which are now submerged below present sea level, and some of which clearly have potential for preser- vation of terrestrial deposits and archaeological material.

All of this makes for a very wide range of different environmental conditions that would have faced prehistoric societies and to which they would have had to adapt, different geomorphological conditions affecting the survival of landscape features and archaeological sites in the face of inundation by sea-level rise, and different opportunities for comparative analysis, with results that are likely to impact on some of the major themes in world prehistory.

\subsection{Sea-Level Change}

Understanding of sea-level change is fundamental to everything discussed in this volume. Generalised diagrams of sea-level change over the Last Glacial cycle, from the Last Interglacial period of high sea level 130,000 years ago through to the establishment of modern sea level in the mid-Holocene, have been used to illustrate archaeological syntheses of European coastal prehistory for over 35 years (Bailey 1983; Shackleton et al. 1984), following the demonstration that $\delta^{18} \mathrm{O}$ measurements of foraminifera in deep-sea sediment cores provide a continuous proxy record of changes in ocean volume (Shackleton and Opdyke 1973; Shackleton et al. 1983). Typically, these early archaeological studies produced maps plotting sea-level variations against modern bathymetry to show the extent of submerged territory at the Last Glacial Maximum or other selected periods.

Since then, measurements of past sea-level change and understandings of the geological and climatic processes involved have, of course, greatly improved but so too has understanding of the scientific complexities underpinning such measurements and the margins of error inherent in them. Margins of error are broadly of two kinds, errors of dating and errors in the vertical positioning of sea level at any given date relative to the modern position. For some archaeological purposes, quite general and imprecise patterns are sufficient to provide useful insights. However, 
as new archaeological questions have led to the demand for greater precision, so too the need to appreciate the uncertainties of the underlying science has become more imperative. This is not always apparent in archaeological texts, which are liable to give a misleading impression of precision by citing specific figures without clarifying the uncertainties involved or to extrapolate global sea-level curves to the region of archaeological interest. Conversely, specialists frequently engage in technicalities that seem of little relevance to archaeological concerns and that many archaeologists are ill-equipped to comprehend.

This situation is further confused by the fact that sea-level change is of interest to several different disciplines, each with different objectives that require different types of data and different degrees of precision. Archaeologists generally want to know to a considerable degree of precision the date and geographical position of palaeoshorelines in their region of interest; palaeoclimatologists are more interested in the global pattern of sea-level variation through time, usually to the highest possible level of measurement, while geologists and tectonic geomorphologists are primarily interested in vertical movements of sea level relative to land in particular regions but not necessarily with the chronological precision required by palaeoclimatologists or the spatial precision required by archaeologists (see Inglis et al. 2019).

From an archaeological point of view, it is important to appreciate two basic problems. The first is the degree of uncertainty involved in measuring changes in sea level that result from changes in ocean volume, that is, changes in the amount of water in the world oceans resulting from the expansion and contraction of the continental ice sheets. This is a global measure, commonly referred to as the ice-equivalent sea level, or esl for short, and roughly corresponds to what is commonly referred to as eustatic sea level. The difference between esl and eustasy is that the latter incorporates changes in the geometry and capacity of the world's oceans to hold seawater as well as the volume of ice-equivalent seawater. The difference between the two measures in the time ranges of interest in this volume, particularly for the late Pleistocene, is small and can be ignored, and the two terms are often used interchangeably.

The difficulty in arriving at reliable measures of global esl is that dated palaeoshorelines provide only fragmented and discontinuous records, compounded by vertical movements of the Earth's crust. More useful are deep-sea sediment records, which provide a continuous sequence of marine sediments and proxy measurements of sea-level variation in the form of $\delta^{18} \mathrm{O}$ variations in the carbonate skeletons of planktonic and benthic foraminifera. They are dateable, and the longest sediment cores extend back over many hundreds of thousands of years. However, they are difficult to relate to the heights of palaeoshorelines without calibration against dated palaeoshoreline features such as submerged or elevated corals terraces, beachrock and peat, or measurements of ice volume. They are also subject to other distortions such as temperature effects on isotopic composition, differences of circulation in different marine basins, bioturbation of sediments, dating errors, and so on. One of the most detailed sea-level curves of this type is from the Red Sea and is based on a variety of proxy measures cross-checked against other palaeoclimate and geological records to construct a sea-level curve over the past 500,000 years (Fig. 1.2; Siddall et al. 2003; Grant et al. 2012, 2014).

As Grant et al. (2014, p. 4) point out, their sealevel curve measures relative sea-level (rsl) relative to a particular geographical region. They produce evidence to suggest that there is an offset between rsl and esl of as much as $10 \mathrm{~m}$ in the Red Sea, especially at glacial maxima, corroborated by detailed studies of vertical land movements (Lambeck et al. 2011).

This raises the second problem for archaeologists and others, and that is that the Earth's crust is not fixed but has been subjected to sustained vertical movements over many geographical scales, some of them in recent geological and archaeological time. These take the form either of isostatic effects associated with loading and 


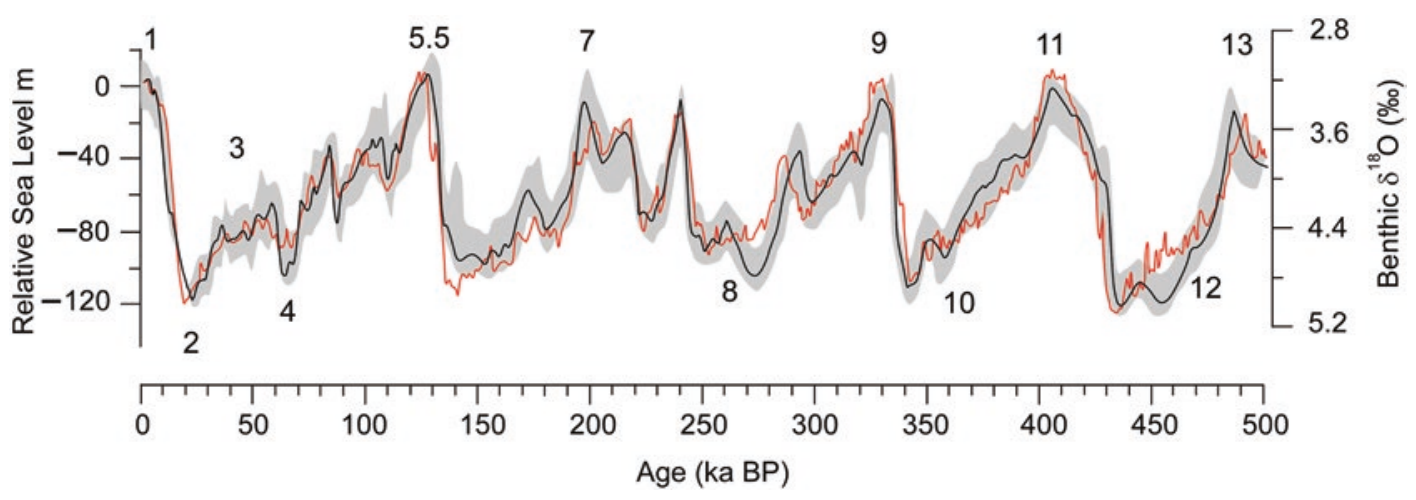

Fig. 1.2 Relative sea-level curve for the Red Sea over the past 500,000 years, based on a variety of proxies including the $\delta^{18} \mathrm{O}$ signal derived from planktonic foraminifera in deep sea sediment cores (black line). The light grey shading indicates the probable margin of uncertainty, including margins of error associated with radiometric dating and the estimation of sea-level position from proxy data. The curve for the past 150,000 years is further constrained by dated palaeoshoreline features and is considered to be the most accurate part of the sequence. The red line is the continuous curve of variation in the $\delta^{18} \mathrm{O}$ signal of benthic foraminifera in deep sea cores from a variety of sources. Also shown are some of the principal marine isotope stages. Data from Siddall et al. (2003) and Grant et al. (2012, 2014). Drawing by Geoff Bailey

unloading of ice sheets and to a lesser extent seawater acting on the continental shelf-GIA (glacio-isostatic adjustment) for short-or tectonic effects, notably at plate boundaries and rifts, where they are associated with uplift or subsidence. Both effects are present in coastal regions of Europe, GIA especially in the northwest in regions of former glaciation, and tectonics in parts of the central and eastern Mediterranean. Harff et al. (2017b) give an extended discussion of these processes with reference to Europe, and examples are also discussed in the relevant chapters of this volume. GIA can extend very widely, well beyond regions of former glaciation albeit with attenuated effect, but is especially prevalent in northern Britain and Scandinavia, where sea level went down initially after the LGM (Last Glacial Maximum) because the land was rebounding faster than sea level was rising. Because of time lags in the Earth response, the land is still rebounding today in areas of Scandinavia formerly located beneath the thickest mass of ice, and the amount of vertical uplift can be hundreds of metres.

Separating out the different contributions of tectonics, GIA, and changes in sea-water volume is problematic because of the difficulty of obtaining fully independent measures of each variable and the combined margins of error associated with each type of measurement. One approach is to look at palaeoshoreline indicators in 'far-field' regions which are tectonically stable and far from GIA effects. A variety of modelling procedures incorporating far-field data have been developed to isolate and refine measures of global esl and to develop models of sea-level change in other regions incorporating whatever dated palaeoshoreline information is available in the region of interest (see Lambeck et al. 2014, for a succinct introduction to the problems of sea-level measurement). Even these models are subject to remaining uncertainties such as the viscosity of the underlying mantle in different regions. Using these modelling procedures and a more detailed data set than Grant et al., Lambeck et al. (2014) have produced an esl curve for the past 35,000 years (Fig. 1.3). Of special note is the evidence for a maximum lowering of sea level of $134 \mathrm{~m}$ at 21,000, the persistence of sea levels at or lower than c. $120 \mathrm{~m}$ below present for a period of 13,000 years between 29,000 and 16,000, and an offset of 10-20 m between their esl curve and the Red Sea rsl curve during this period.

Also of note is the evidence that sea level did not stabilise at about the present position until 2000 years ago. The commonly cited date of 


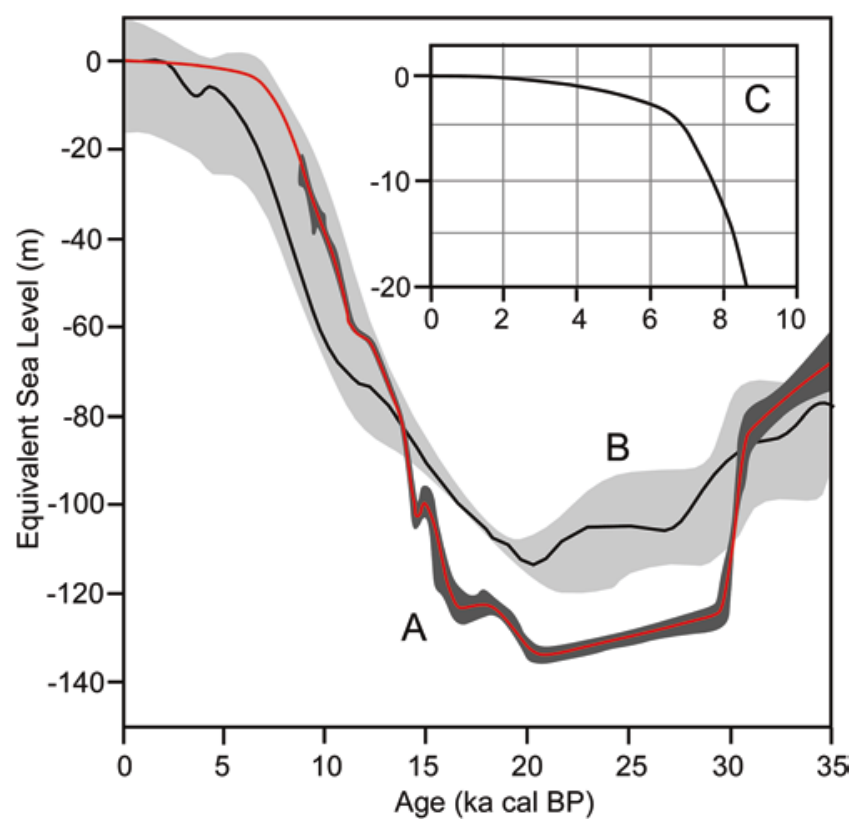

Fig. 1.3 Comparison of the global ice-volume equivalent (eustatic) sea level (esl) with the relative sea-level curve from the Red Sea for the last 35,000 years. A (red line): the esl curve with the statistical margin of measurement error at the 95\% probability level (dark grey). B (black line): the relative sea-level curve from the Red Sea with its margin of uncertainty (light grey). C (Inset): the esl curve for the past 9000 years (the legend for the figures on the axes is the same as for the main image). Note that the maximum depth of sea level in A is $-134 \mathrm{~m}$ at $21 \mathrm{ka}$ and that a period of low sea level at $\geq 120 \mathrm{~m}$ lasted from 29 to $16 \mathrm{ka}$. Note also that the two curves correspond quite well within the margins of uncertainty except for the period of the LGM, when there is an offset of 10-20 m. Note also that the rate of rise in the esl drops sharply between 8.2 and $6.7 \mathrm{ka}$, corresponding to the final melting of the North American ice sheet, but that the esl continues to rise more slowly through another $3 \mathrm{~m}$ before fully stabilising. See text for further discussion. Data in A and $\mathrm{C}$ are taken from Lambeck et al. (2014) and in B from Fig. 1.2. Drawn by Geoff Bailey

$6800 \mathrm{cal}$ BP for the final melting of the northern hemisphere continental ice sheets is sometimes used as a proxy measure for the date when sea level stopped rising. However, the esl data in Fig. 1.3, while they show a marked drop in the rate of sea-level rise at that date, also demonstrate a continued slow increase of sea level through about 3 m until 2000, most probably because of continued melting of ice from the Antarctic and Greenland ice sheets.

In addition to the issues discussed above, there are yet additional variables that need to be taken into account when assessing relative sea-level position and the configuration of palaeoshorelines at a regional or local scale. In the regional, semi-enclosed seas of Europe, for example, the effect of variations in wind strength and direction and barometric pressure can affect sea level
(Harff et al. 2017b). Shorelines of softer materials such as Pleistocene sediments are also vulnerable to lateral shifts in shoreline position because of erosion or progradation, especially during periods when sea level remains at about the same level for long periods, processes that have been well studied in the Holocene (Harff et al. 2017b). Changes in the depth of the seafloor because of accumulation or erosion of marine sediments since the time of archaeological interest can also affect the reconstruction of palaeogeographic contours and shorelines from present-day bathymetry.

The upshot of the above discussion is that archaeologists interested in plotting the impact of sea-level change on their archaeological data and their region of interest should be aware of the margins of uncertainty involved in the primary 
measurements, the incompleteness of the underlying science, and the hazards of extrapolating global sea-level curves to particular regions or from one region to another. Statements of a single measurement for archaeologically important benchmarks, such as the maximum lowering of sea level at the LGM or the date when sea level stopped rising during the postglacial period, risk imputing a misleading sense of accuracy unless they are qualified by a suitable error term.

Ultimately there is no substitute for the discovery and dating of local palaeoshoreline features in the region or locality of archaeological interest. Dated palaeoshoreline features from below modern sea level that can help to refine models of sea-level change are relatively rare and much sought after. Underwater archaeological sites, especially if they were originally located on the shoreline and can be well dated, which is often the case, are therefore of great interest to sea-level modellers, and archaeologists and sealevel specialists can make common cause in the search for such data to mutual benefit.

\subsection{Organisation and Scope}

The initial compilation of data for the SPLASHCOS Viewer and the subdivision of tasks undertaken by the members of WG1 was organised by each modern nation state, reflecting the practical reality that scientific and academic research institutions, government agencies responsible for cultural heritage, and the conduct of field research are largely organised at national level. This has carried through to the chapters that form the basic building blocks of this volume, which present a series of national overviews. However, modern state boundaries are a poor fit with the environmental features that are of primary relevance in the interpretation of the underwater archaeological record. They risk placing data into arbitrary categories that inhibit supra-national integration and obscure the understanding of variables that go across modern political boundaries.

\subsubsection{National Overviews and Marine Basins}

The arbitrary nature of modern state borders is especially the case when dealing with the coastal zone and the offshore submerged landscape, where the primary geographical unit of study is the ocean or marine basin to which the coastal margins of individual countries relate. Moreover, Europe with its regionally varied coastal geomorphology and continental shelves has presented us with the challenge of how best to arrange the sequence of national overviews and how best to group them so as to highlight relevant similarities and contrasts.

For the principal subdivisions of the book, we have taken the major marine basins as our primary unit of organisation: the Baltic, the North Sea and Atlantic, and the Mediterranean and the Black Sea. Each has its own distinctive characteristics that provide a coherent whole and a unifying focus for transnational comparisons, and these categories also facilitate comparison with the more detailed information on Quaternary palaeoenvironments presented in the Flemming et al. (2017a) companion volume, which is structured along similar lines. A case could be made for further geographical subdivision, for example, between the North Sea and the Atlantic coasts of Western Europe, between the different sectors of the Mediterranean, or between the Mediterranean and the Black Sea, but this has to be tempered by the quantity and detail of the available archaeological data. This is heavily concentrated around the coastlines of a small number of countries in Northwest Europe, especially those bordering the North Sea and the western Baltic, which have the longest histories and the best-developed traditions of underwater investigation and collaboration with offshore industries, whereas the archaeological data elsewhere is much patchier (Fig. 1.1).

A complicating factor is the fact that some countries have two coastlines. France, for example, has an Atlantic and a Mediterranean coastline and Denmark a North Sea and a Baltic one. 
Conversely, some marine basins are only partially represented in our coverage: the Mediterranean, in particular, is represented only by its northern and eastern shorelines, and the North African coastline is absent, despite its importance in prehistory. This reflects both the absence of known underwater prehistoric remains and the lack of participants from the North African countries in the SPLASHCOS Action. ${ }^{2}$ Similarly, the Black Sea is represented by only two national contributions (Bulgaria and Ukraine). Also, the Baltic is only represented by the countries at the western end (Germany, Denmark, and Sweden). Again, this reflects, in part, the near absence of underwater archaeological data to the east and the north, but more importantly the impact of glacio-isostatic rebound, which means that the archaeological evidence for the earliest settlement of coastlines in these areas after the retreat of the Scandinavian ice sheet is now mostly uplifted above modern sea level.

With all these factors in mind, we have used three primary groupings to organise the national overviews: the Baltic and Scandinavia (including Norway) (Part I), the North Sea and the Atlantic (Part II), and the Mediterranean and the Black Sea (Part III). These are broad groupings that reflect a compromise between the ideal subdivisions derived from environmental considerations and the relative proportions of archaeological data and investigation distributed across the continent. We recognise that this grouping introduces arbitrary boundaries of its own, and we have dealt with this by introducing each of our main groupings with an editorial introduction, which highlights the features of the national overviews within that grouping, addresses relevant aspects of within-basin variability and inter-basin boundary issues, and incorporates such information as is available from isolated underwater archaeological finds elsewhere and not represented in the national overviews.

${ }^{2}$ COST rules certainly cover the funding of representatives from these countries, but we were unsuccessful in our attempts at recruitment.
Two chapters are from countries (Malta and the Ukraine) that currently have no known underwater finds (apart from a worked flint in a core recovered from the north-west shelf of the Black Sea). The reason for their inclusion is that they are all countries where underwater survey has been carried out with archaeological questions in mind and with prospects for future discoveries.

We have chosen to present the groupings and their constituent chapters in geographical order, beginning with the Baltic, and working in an anticlockwise direction through the North Sea and Atlantic coastlines, and thence through the Mediterranean Sea and the Black Sea working from west to east.

The choice of the Baltic as our starting point reflects the fact that this region has the best developed tradition of underwater prehistoric archaeology in Europe-and indeed the World - the largest number of practitioners, and by far the largest number of currently known prehistoric underwater sites. These include settlement sites and burial grounds in Denmark and Germany such as Tybrind Vig, Møllegabet II, and Timmendorf-Nordmole that demonstrate the quality and detail of preservation in sediments rapidly submerged under the advancing sea, with remains of wooden artefacts, fish traps, dugout canoes, paddles, plant fibres, wooden structures, and other organic materials. It is also a region that highlights the dramatic interplay between sea-level rise at the end of the Last Glacial Period and the glacio-isostatic adjustments associated with ice melting - uplift of the territory formerly depressed under ice cover in Scandinavia and sinking of territory and coastlines around the former ice margin-resulting in alternations between periods when damming of the Baltic turned it into a freshwater lake basin isolated from the North Sea and periods of reconnection involving dramatic episodes of flooding and complex patterns of palaeogeographical and ecological reconfiguration; these must have had a correspondingly dramatic impact on the preexisting human populations of the region. Because of its glacial history, evidence for human 
activity earlier than about 15,000 years ago is absent and at this early date only in Denmark. Elsewhere, earliest dates are closer to 10,000 years ago or soon after, sites of this age being present both on uplifted coastlines (as in Norway) and on submerged coastlines (in southern Denmark and Sweden).

Our second regional grouping (Part II) is dominated by finds from around the North Sea, especially in British and Dutch territorial waters and to a lesser degree along both coastlines of the English Channel/La Manche and the coast of Belgium. The finds from this region extend the underwater prehistoric record into deeper water and further back in time, at least as far back as 300,000 years ago, and in the case of human footprints in intertidal sediments in Britain back to the earliest known human presence in the region nearly one million years ago.

These finds include a large and important group of sites exposed in the intertidal zones of Britain and along the Atlantic coastlines of northern France including partially submerged human footprints and megalithic structures, and some systematic excavations of fully submerged sites, notably the Mesolithic site of Bouldnor Cliff on the Isle of Wight and, directly opposite across the Channel, the Middle Palaeolithic site of La Mondrée, Fermanville, on the Normandy coast of France.

Further offshore, large quantities of Ice Age fauna, numerous stone artefacts, and lesser quantities of human bones including part of a Neanderthal skull have been dredged up from the seafloor by fishing and gravel extraction. Although little is known about the provenance of many of these finds, efforts are now being devoted to pinpointing their location and obtaining new information. In addition, new and important material has been recovered through large-scale operations made possible by collaboration with industrial companies working offshore.

One good example is the systematic investigation during the past decade of the submerged Mesolithic site of Maasvlakte-Yangtze harbour on the Dutch coast, associated with the construction of new harbour facilities (Moree and Sier 2015). This marked an important turning point in demonstrating the possibilities for discovery of prehistoric remains buried beneath marine sediments. Here a stepwise process of acoustic and geological survey identified likely target areas, followed up by coring of sediments for traces of human activity and large-scale excavation in the most promising localities. Another good example is the A240 site off the east coast of England (Tizzard et al. 2014; 2015), where discovery of artefacts in the gravel spoil from aggregate extraction led to sampling of the sediments in the vicinity of their original discovery and the recovery of larger quantities of artefacts and palaeoenvironmental data from dateable sediments (see chapters in Part II and Part IV for further details).

In addition, analytical techniques such as radiocarbon dating and stable isotope analysis of palaeodiets can be applied to chance finds dredged up from the seabed, regardless of their provenance, revealing new information about the environmental features of the submerged landscape and the nature of human adaptations to them. The recovery of ancient DNA from buried sediments (sedaDNA) offers a new technique for gaining insight into the plants and animals present in the pre-inundation landscape.

The Mediterranean-Black Sea region is our most disparate and widely scattered collection of material (Part III). It includes an important group of finds on the Mediterranean coastline of France, including the famous and partially submerged rock-art site of Cosquer Cave and other submerged karstic caves with evidence of preserved terrestrial sediments containing artefacts and fauna. Elsewhere, there is a wider scatter of submerged sites in Italy, Croatia, Greece, Cyprus, and Bulgaria, mostly submerged or partially submerged in shallow water, and including the important submerged sites of Pakostane and Zambratija in Croatia, Agios Petros, and Pavlopetri in Greece, submerged and wellpreserved Chalcolithic and Early Bronze Age village settlements in Bulgaria, and another concentration of expertise and discoveries on the Carmel coast of northern Israel including the underwater Pre-Pottery Neolithic Village of Atlit Yam, one of the most intensively studied underwater sites in the world. Israel has a tradition of 
researching underwater prehistoric sites, which, as in Denmark, goes back to the 1970s. The number of sites, though relatively small, and extending in time only back to about 9000 years ago, demonstrates the extraordinary range and quality of evidence that can be recovered from systematic underwater survey and excavation extending over a period of many years. It is fitting that the finds from these opposite ends of our geographical range should provide the opening and closing chapters, respectively, of the national overviews.

\subsubsection{The Industrial, Legal, and Commercial Context}

Most of the national overviews with underwater finds include a section at the end of the chapter on the management of the underwater cultural heritage and the responsible governmental agencies or other institutions. This is an issue of major importance, given the growing threats from a variety of causes, especially intensifying commercial and industrial exploitation of the seabed, but also including natural processes of erosion, some of which are being accelerated by recent climate change. From its very beginnings early in the twentieth century through to the present day, the history of underwater investigation of the submerged landscape has been intimately connected with the progress of offshore commercial and industrial activity (Sturt et al. 2017). Sometimes this leads to tensions and conflicts between the needs of scientific and archaeological research and the regulations and resources available to protect and manage the underwater cultural heritage. Accordingly, Part IV brings together a group of chapters that examine legal, historical, and managerial issues associated with offshore and underwater work and its relationship to commercial and industrial exploitation of the seabed, issues that are of paramount importance to the present practice of underwater archaeology and the prospect of future discoveries.

Much of the underwater research in NW Europe is being carried out by commercial archaeological companies in response to the requirements imposed by legislation on offshore industries to undertake initial investigation and impact assessments in advance of offshore developments such as wind farms, construction of port facilities, and building of bridges and tunnels. In some cases, these have resulted in high-profile projects involving collaboration with industrial companies and major discoveries that would not otherwise have been possible. Notable examples, as mentioned earlier, are the A240 Project, in collaboration with gravel extraction companies in the United Kingdom, and the expansion of the Yangtze harbour in collaboration with the Port of Rotterdam authority in the Netherlands. Some of these projects provide funding and equipment on a scale that far exceeds the normal research budget, and the results are of benefit to all concerned, producing important archaeological discoveries as well as good publicity and wider public interest. Increasingly it is archaeologists in the commercial sector of the community who are developing the skills and experience and who are able to command the resources to conduct such investigations. Typically, this type of work involves a three-way relationship between the industrial companies, archaeologists, and government agencies responsible for managing the underwater cultural heritage. The issues that arise from this relationship are considered from a variety of perspectives in this final group of chapters.

\subsection{Boundaries and Definitions}

An important issue is the question of the uppermost chronological boundary for the finds that we include in our survey. At an early stage, we agreed that work should concentrate on underwater archaeological finds no later in date than the time when the ocean-volume equivalent (or eustatic) sea level stabilised after the melting of the continental ice sheets, that is to say at about 6000-5500 cal BP, a date that marks the approximate boundary on many European coastlines between the end of the Stone Age and the beginning of the Bronze Age. Our aim, after all, is to highlight the significance of now-submerged 
territory and to promote its study. However, this is an arbitrary boundary and raises two important issues.

\subsubsection{Chronological Issues}

The first issue is that, as discussed earlier, relative sea-level rise continued later than this limit of 5500 years ago on some coastlines, whether from continued addition of glacial meltwater to the oceans or continuing land subsidence resulting from isostatic or tectonic processes. Tectonic effects associated with relative plate motions in the eastern Mediterranean, especially subduction in the Aegean, are causing stretching of the Earth's crust and long-term subsidence. Some important later prehistoric settlement sites have been partially or totally submerged in consequence and provide relevant and interesting examples of what survives the process of inundation in shallow water.

There is also an interesting category of finds that represents the deliberate and ritual deposition of votive offerings under water, rather than materials accidentally lost overboard during fishing expeditions or sea crossings. These are well known from Bronze Age times onwards, or at least more easily identifiable because of the types of metal artefacts found, but this practice may have existed in the Stone Age, when it is more difficult to distinguish from the stone tools whether they represent the byproduct of day-today subsistence activities or ritually deposited material.

We have encouraged the authors of the national overview chapters to take a flexible attitude to this chronological boundary, while emphasising that the primary focus should remain on pre-inundation landscapes of the Stone Age and archaeological evidence that informs on the occupation and use of those landscapes when sea level was lower than the present.

Many coastlines of Northwest Europe harbour later evidence of maritime activities and material culture in partially submerged or waterlogged coastal wetlands, or on shores that have become covered by marine sediments because of progres- sive landward erosion, sometimes with excellent preservation of features such as wooden fish traps, trackways, landing stages, and remains of wooden boats, extending in date right through to recent historical periods. Similarly, in the tectonically active regions of the Eastern Mediterranean, notably in Italy and Greece, there is a plethora of stone-built harbours, landing stages, fish tanks, and other shoreline buildings and facilities of Classical and later date that have undergone partial or total submergence because of land subsidence. We consider these to be outside the scope of this volume, although they may receive a brief mention in some of the national overviews.

\subsubsection{Radiocarbon Chronologies}

A subsidiary issue that should be mentioned here is the conventions for citing dates, which are the subject of ongoing confusion. Within the time range of radiocarbon dating, many dates are radiocarbon ages. However, it is well known from dendrochronological calibration that radiocarbon ages deviate significantly from calendar ages, especially during periods critical to our enquiry, such as the late glacial and early postglacial periods, when the deviation may be as much as 2000 years, with occasional plateaux or even reversals. Radiocarbon ages therefore need to be calibrated if they are to be compared with calendrical or other dating schemes. We have therefore encouraged our authors to stipulate whether ages derived from radiocarbon dating are radiocarbon ages, usually expressed as a figure with a \pm statistical margin of error indicating one standard deviation (a $68 \%$ probability that the true value lies within the stated margin), or calibrated dates, usually indicated by the suffix cal (cal BP or cal $\mathrm{BC}$ as the case may be) and sometimes expressed as a range of dates at two standard deviations (95\% probability).

The situation is further confused by the preference amongst archaeological specialists of Neolithic and later periods for the BC (or BCE)/ $\mathrm{AD}$ convention, and amongst many Palaeolithic and Mesolithic specialists for the BP convention, while palaeoenvironmental specialists prefer to use BP (without the cal prefix) when referring to calibrated dates. In older literature before calibra- 
tion was widely applied, dates are given as BC or $\mathrm{BP}$ without qualification but usually meaning that they are uncalibrated radiocarbon years. Other conventions are 'years ago' or 'ka' (thousands of years ago), which usually refer in a general way to years before the present, where closer accuracy is not required. There is at present no agreed solution to these different conventions, and wherever possible dates in this volume are expressed in a way that hopefully makes clear their derivation.

\subsubsection{The Ambiguity of the Land- Sea Boundary and Issues of Definition}

The question of chronology raises a second important boundary issue and that is the issue of how we define 'under water', where we draw the line between dry land and submerged land and hence between terrestrial archaeology and underwater archaeology. Strictly speaking, all investigation of past human landscapes is terrestrial archaeology, whether these landscapes are now below modern sea level or above it, and ideally both should be treated together as a seamless whole, with the present-day shoreline as an arbitrary and largely irrelevant boundary until sea level reaches the modern level. However, there are practical issues that complicate this simple vision.

The first complication arises from how we define an underwater site. A minimum definition for our purposes is any archaeological material originally deposited on a dry land surface that has subsequently been inundated by relative sea-level rise. This includes archaeological material in the intertidal zone or shallow water up to and including the high-water mark at the time when these pre-inundation land surfaces were in use, for example, abandoned dugout boats, fish weirs, or domestic refuse discarded into shallow water by people living on settlements located on the shoreline.

This in its turn raises a second complication, and that is how we are to deal with evidence found in the modern intertidal zone. Here there is a major contrast between different regions. The Atlantic and North Sea shorelines of Western Europe are exposed to large tidal ranges-as much as $14 \mathrm{~m}$ in some parts of Britain-with intertidal zones that can extend at low tide for many hundreds of metres or even kilometres out from the present-day shoreline. In the Baltic, Mediterranean, and Black Sea Basins, the tidal range is almost everywhere tiny by comparison, measured in tens of centimetres, though the amplitude may be increased a little by other effects such as variations in winds and barometric pressure.

In basins with minimal tidal ranges, the boundary between land and sea is quite sharp and invariant, and it is usually obvious what constitutes underwater archaeology deposited on a land surface that was subsequently inundated and what constitutes terrestrial archaeology above modern sea level. Underwater sites may occur at varying depths; some are in water shallow enough that one can stand on the seabed without putting one's head under water, but it is clear that the material has been permanently submerged since the time of inundation (with rare exceptions) and that closer investigation and excavation requires divers, other standard methods of underwater investigation, and assessment of how deposits and materials have been affected by inundation.

In the case of Atlantic coastlines, the boundary between land and sea is much less sharply defined, and the question of what constitutes terrestrial as opposed to underwater archaeology is highly ambiguous. Many artefacts have been recovered from these intertidal zones and may represent (a) in situ material on an old land surface that has been covered by marine sediments and then re-exposed by stripping away of the overlying sediments by tidal action or storms, (b) material that has been eroded out from a more deeply submerged land surface and washed ashore, or (c) material that has been eroded out from terrestrial deposits on the landward side of the modern shoreline such as cliffs or raised beaches and redeposited on the modern beach. Clearly category (c) material cannot count as evidence for the use of a submerged land surface and should therefore be excluded from our statistics 
for underwater sites. However, it is often not possible to distinguish between these possibilities without careful and detailed investigation. With many isolated specimens, it may prove impossible to identify which of the above categories they belong to, in which case the finds should be excluded from the underwater category.

Moreover, archaeological investigation of these extensive intertidal zones in Northern Europe, notably in France and Britain, is usually carried out as an extension of land-based archaeology, with survey on foot and excavation of material during periods of exposure at low tide using conventional land-based techniques. Yet, some of the ancient land surfaces and archaeology exposed at extreme low tides in Britain that have been investigated in this way are earlier in date, at greater distance from the modern shoreline, and deeper below mean sea level, than some of the sites in Denmark, Germany, and Sweden that are permanently under water and have been investigated by divers. In both cases the archaeology refers to the use of a landscape that was subsequently inundated by sea-level rise. In the former case, however, the material is treated as an extension of archaeological investigation on land, and the low-water mark is the limit beyond which investigation does not go; in the latter case, the material is treated as part of the underwater record, and the high-water mark defines an upper limit below which investigation may proceed to any depth and distance from the shore that is within reach of SCUBA technology or acoustic survey. The British and Scandinavian traditions of investigating archaeology at the land-sea boundary are, thus, highly divergent, reflecting the very different tidal regimes and research traditions in each region. Both have resulted in major projects leading to information about the use of submerged landscapes, but the British projects are centred around the investigation of coastal wetlands and the Danish projects around the investigation of underwater settlements.

A further difficulty is the fact that some coastal sites on dry land that have never been inundated by sea-level rise nevertheless do not make sense as places of settlement or activity except in relation to a landscape that is now submerged. They may contain important archaeological evidence for the exploitation of resources, particularly marine resources, on that now-submerged land surface. Coastal caves above modern sea level are especially relevant here because they sometimes contain stratified deposits with deeper layers that extend back in time to a period of lowered sea level. These are present on many European coastlines especially in Southern Europe and are referred to in the relevant national overviews even though they do not constitute underwater sites in the strict definition of that term.

Until recently, specialists of the Palaeolithic and early Mesolithic periods have been at risk of building false interpretations around a body of data that represents the truncated hinterland fragment of a wider landscape, most of which is now submerged and is therefore ignored. It is equally important that, in the interests of promoting underwater research, we do not fall into the opposite trap of excluding information relevant to understanding the human use of now-submerged landscapes by defining too strictly the limits of study and confining our attention only to archaeological material that is fully submerged below present sea level.

Another category of archaeological interest that blurs the boundary between land and sea is 'wetlands' archaeology, which has a long tradition of study especially in Europe (e.g. Coles 1984, 1992; Menotti and O'Sullivan 2012). Here the emphasis is on waterlogged material, with its unusual opportunities for preservation of organic materials, especially wood, whether in underwater contexts on submerged coastlines, in shallow marine inlets and fjords as in Denmark that have been drained in more recent times but retain waterlogged sediments and preserved organics remains, or in inland lake basins. It is no coincidence that Grahame Clark, the founder of Mesolithic studies in Britain and the economic approach to prehistory, immediately recognised the significance of the Colinda harpoon dredged up from the North Sea in 1932, the same year that he founded the Fenland Research Committee, or that he was simultaneously engaged in researching the submerged landscapes along the Essex coastline in the 1930s alongside the wetlands of the East Anglian hinter- 
land (Smith 1997; Sturt et al. 2017; Bailey et al., Chap. 10, this volume).

There is no simple solution to these definitional dilemmas other than to recognise that the boundary between underwater and abovewater archaeology is a blurred one, and to refer to the wider context of the terrestrial archaeological record where it is relevant to the primary focus of this volume, which is an understanding of the submerged landscapes and the underwater archaeology belonging to earlier periods of prehistory when sea level was lower than present.

\subsection{The SPLASHCOS Viewer}

The SPLASHCOS Viewer is a simple digital inventory of underwater archaeological sites around Europe's coastlines, linked to a digital map of Europe. At present, it contains 2640 individual records, ranging from find spots that consist of a single artefact to underwater settlements that have been systematically excavated and generated thousands of finds (Appendix I; Fig. 1.1). It is publicly available as an online GIS and includes summary data about each site and its location so that users can filter information in accordance with their own research interests. Online access is intended to support scientific research and to promote the ideal of open science. Data are organised by nation state and have been compiled by the authors of the national overviews presented in this volume. The Viewer is the source of information for the distribution maps of archaeological sites presented throughout this volume and for the tabulation of site information presented in some of the chapters. Full details about the compilation of the data in the Viewer and the accompanying maps are presented in Appendix I, together with summary statistics for Europe as a whole, and for the major marine basins which form the structure for the chapters in this volume.

The SPLASHCOS Viewer has a permanent home at the Lower Saxony Institute for Historical Coastal Research, Germany, where the data are collated and managed, and the online information is on servers maintained under EU auspices and available at http://splashcos.maris2.nl/ and at http://splashcos-viewer.eu/. Arrangements are in place to include new data as it becomes available. By providing a permanent and publicly available source of scientific data, and one that can be linked to other online platforms, the intention is to promote the agenda of scientific research on submerged landscape archaeology, raise public awareness and interest, and contribute to the management and protection of the underwater cultural heritage.

\subsection{Conditions of Preservation and Discovery}

One of the striking features of the map shown in Fig. 1.1 is the very marked variation in the number and distribution of archaeological sites in different regions, with the largest concentrations in the western Baltic and around the coastlines of the North Sea and the English Channel/La Manche. This naturally provokes the question of why this is so, and the extent to which it is due simply to differences in the intensity of investigation and the availability of skills and training, or rather to variable conditions of preservation and exposure, or to a combination of factors.

There is no doubt that the concentration of finds in Northwest Europe is in part the result of a long history of interest and development of skills and methods of underwater investigation over the past 40 years. Other related factors are the importance of postglacial sea-level rise and palaeogeographical changes in understanding the colonisation of the region after glacial retreat at the end of the Last Ice Age; the importance of marine resources, coastal travel, and shoreline settlements in the early development of the Stone Age cultures that moved into this new territory; high levels of awareness and interest amongst a wider public, with reporting of finds by beach combers, recreational divers, and fishermen; and in the past decade industrial collaborations that have made possible large-scale investigations in deeper water with some impressive results.

Equally, one could argue that this high level of early interest is itself in part due to the abundance 
of underwater archaeological material and its exposure by erosion in shallow water and in the intertidal zone where it is easily visible to the casual observer. However, similar levels of public interest, professional training in underwater archaeology and recreational diving are present in other regions, notably in the Mediterranean. Here, however, the focus of interest has been on submerged harbours and other shoreline features of Greek, Roman, or later date, on shipwrecks, and on refining measurements of the interplay between sea-level change, isostasy, and tectonic instability, rather than the submerged landscapes of the Stone Age.

Differences in preservation conditions resulting from variations in offshore topography, sedimentary regimes, and oceanographic conditions are also implicated. A detailed examination of these matters can be found in Flemming et al. (2017b), and more specific data on the conditions of preservation and discovery associated with archaeological discoveries are presented in the national overview chapters in this volume. This issue is of obvious relevance under water, given the expectation that so much material has likely been disturbed, destroyed, or submerged by sealevel rise. But it applies equally to archaeology on land and has given rise to a growing interest in 'landscape taphonomy' - analysis of the variable conditions associated with the initial deposition of archaeological material and the subsequent processes of preservation, burial, disturbance, exposure, and destruction. Lest the terrestrial archaeologist be tempted to consider the search for submerged archaeology as a lost cause, it should be emphasised that these problems of differential preservation and visibility apply with equal force on land, and perhaps more so, because of extensive disturbance and destruction of the land surface by agricultural and industrial activities, to say nothing of erosion by wind and rain. These processes, of course, simultaneously destroy or obscure but can also expose to archaeological discovery the buried remains of past human activity, and this point applies with equal force above and below modern sea level.

One of the paradoxes of discovering submerged remains of Stone Age archaeology is that the best chances of preservation are where material is covered fairly rapidly by a protective layer of marine sediment. However, that process in itself removes the archaeological material from view and continues to bury it under everthickening layers of sediment unless the material is subsequently disturbed by storm activity, submarine erosion, or other intrusive methods such as dredging, trawling, coring and drilling, or industrial-scale excavation. In basins of heavy sediment accumulation, such as those that rim many of the southern shorelines of the North Sea, the accumulated thickness of recent marine sediments is so thick that the prospect of discovering the buried land surface may be very low indeed. Accumulation of protective sediment cover is thus a key factor in long-term preservation, but subsequent exposure by erosion or other means is also a necessary accompaniment to discovery. The presence of so many finds in shallow water near the modern shore or in the intertidal zone probably has as much to do with the erosional effects of wave action and shallow-water currents as with their relative ease of accessibility.

Two fallacies about the underwater survival of archaeological remains should be mentioned here: one is the belief that the best chances of survival are during periods of rapid sea-level rise or-which may amount to the same effectslower sea-level rise on very gently shelving shorelines; the second is the belief that the worst chances of survival are on open coastlines exposed to the full force of waves, winds, and turbulent currents. Neither is true as a generalisation, and there are many examples in this volume that give the lie to such statements. No rate of sea-level rise can be so rapid that it spares the archaeological finds from a prolonged period of exposure to the potentially destructive effects of wave action in the surf zone or to the turbulence of shallow-water currents. Even the steady lapping of gentle currents against shorelines in protected bays can very quickly undermine and displace unconsolidated archaeological deposits. The one positive consequence of rapid inundation that should be mentioned is that it can cover perishable organic materials such as wood or other delicate materials and features before they 
are destroyed by bacterial attack and subaerial erosion and thus helps to ensure their long-term preservation in anaerobic conditions.

As for storm-exposed beaches, the very storminess that at first sight seems so destructive actually contributes to the accumulation of sediments that protect the older land surface and then strips away parts of this protective cover to re-expose the earlier surface. The number of submerged forests, peat beds, and archaeological features discovered in the exposed intertidal zones and shallow waters of Northwest Europe, and the stone structures in the eastern Mediterranean, are sufficient testimony to this process.

Although generalisations should be treated with caution, there are nevertheless some general variations at the European scale that influence the likelihood of preservation and discovery and the types of underwater deposits and archaeological materials available for investigation. There are major differences in the width and gradient of the continental shelf, and the accumulated thickness of sediments, especially between Northwest Europe and the Mediterranean (Fig. 1.1). The prevalence of submerged forests and peat beds is a characteristic feature of the shallower shelves of Northern and Western Europe, and many sites in the shallow waters and extensive intertidal zones of this region have been protected and preserved by these organic deposits. The concentration of archaeological finds in the inner archipelagos of Denmark and the southern Baltic most likely relates in part to a relatively shallow sea floor, relatively calm and protected sea conditions with limited exposure and tidal amplitude, and extensive deposits of submerged peat and relatively easy visibility of eroding materials in shallow water at the shore edge. Many of the coastlines around the North Sea and along the coasts of the English Channel/La Manche are also basins of sediment accumulation because of long-term subsidence and the volume of sediments introduced from the catchments of the major European river systems that drain into these basins.

Conversely, much of the Mediterranean coastline, particularly in the more tectonically active regions of the central and eastern Mediterranean, comprises steep and rocky coastlines, with hilly or mountainous onshore topography, coastal cliffs, steeply sloping offshore shelves, and more limited accumulations of offshore sediment. In these circumstances, coastal caves, both onshore and below sea level, offer prospects for obtaining information about the use of the submerged landscape. It is also of interest and reflects to some extent the same sort of coastal geology and geomorphology that some of the best-known underwater sites in the region, such as those of Greece and Israel, have become visible because of remains of stone structures easily spotted on the seabed, rather than from exposure of submerged peats, stone artefacts, or faunal remains. There are, of course, exceptions to these broad generalisations, notably in the Golfe du Lion off the Mediterranean coasts of Northeast Spain and Southern France, the Northern Adriatic, and the Western Black Sea, where shallow basins of sediment accumulation and peat formation are present, associated with the estuaries of large rivers such as the Rhone, the Po, and the Danube. These areas have good conditions of preservation, have already yielded evidence of submerged settlements, and have good potential for future discoveries.

However, these are very broad differences and should be compared with more detailed information in the individual chapters of this volume and in Flemming et al. (2017a, b). The key to the prospects for archaeological preservation and discovery lies as much in localised features as in the more general characteristics of coastal zones, and that can only come from detailed investigations at a regional and local level.

Another factor that may be relevant to the differential distribution of underwater finds across Europe is the availability of funding and equipment, some of which is expensive and highly specialised, especially where large ships are required. This is not the place to elaborate on the techniques of underwater investigation. Details of methods, equipment, and strategies can be found elsewhere (Galili et al. 2017; Holmlund et al. 2017; Missiaen et al. 2017; Uldum et al. 2017) and some examples of their application in the following chapters. Nevertheless, it is worth empha- 
sising that many of the finds reported in this volume were discovered or more intensively explored and excavated by relatively simple means, on foot at low tides on the more extensive intertidal zones of the north-west, or in shallow water with small boats, simple equipment and small teams of SCUBA divers as pioneered in Denmark (Fischer 1995, 2004). Research in deeper water in collaboration with industrial partners is also more advanced in Northwest Europe, a partnership that can supply big ships, complex equipment, support teams, and engineering solutions, often at minimal cost. Arguments against conducting underwater research on grounds of cost or technical complexity have been largely superseded by the growing number of projects based on one or other of the above strategies.

\subsection{Research Themes}

Deployment of resources and personnel, especially where significant funding is involved, if it is to be justified, does of course require intellectual justification in terms of worthwhile problems that require underwater investigation and that cannot be solved in any other way. A variety of ideas and themes are presented throughout this volume, and we offer here only the briefest summary.

Major themes include the earliest colonisation of Europe and the major routes and pathways by which our hominin ancestors entered Europe from Anatolia and Africa. Large areas of submerged landscape are likely to have offered extensive lowlands dotted with lake basins, springs, and stream channels, especially in the eastern Mediterranean, offering attractive resources for hunting and gathering around lake basins, and along palaeocoastlines and nowsubmerged river channels. These would have provided broader and more easily accessible and traversable land connections around many coastal regions of the Mediterranean and the Black Sea than is the case in the present-day coastal topography. Similar comments apply to the extensive shelf regions of Northwest Europe and their role in the earliest colonisation of the region or its recolonisation after periods of glaciation.

Early sea travel, whether involving simple methods of rafting or more organised seafaring with early canoes or boats, is also a current topic of high interest, with evidence that sea crossings and the use of islands in the eastern Mediterranean were being accomplished in the late Palaeolithic period well before the spread of pioneer farmers, and perhaps as early as the Middle Palaeolithic (Ammerman and Davis 2013, 2014). The key lies in archaeological evidence for human presence on islands, and some of the claims of earliest dates remain controversial. Regardless of these controversies, it is clear that evaluation must depend on reconstruction of palaeoshorelines and sea-crossing distances at periods of low sea level when the palaeogeographic configuration of coastlines and islands would have been quite different from the present-day pattern. Moreover, the earliest locations of landfall and departure and the archaeological evidence for them must, by definition for periods when sea level was lower than present, lie on now-submerged shorelines.

As with early population dispersals, so with the more recent spread of farming in the Neolithic from centres of origin in Anatolia and the Near East, coast-wise patterns of dispersal figure prominently in interpretations, and the period of earliest agricultural dispersal was at a time when sea levels and coastlines were still somewhat lower than the present, again reinforcing the need for underwater research and the likelihood that present understandings are limited by the rarity of such investigations.

Another major theme is the time depth of human interest in the use of marine resources and the establishment of permanent settlements on the coast sustained by the abundance of marine foods. By the time that Mesolithic coastlines become visible on the postglacial shorelines of Northwest Europe, it is clear from food remains in archaeological deposits and stable isotope signatures in human skeletons that marine foods and permanent settlement on the coast were a major feature of the period. Moreover, it is clear from the uplifted coastlines of Norway and Western 
Sweden that seafaring and hunting of sea mammals were a necessary accompaniment to earliest human dispersal in these higher latitudes and the provision of storable marine foods with their high fat content, without which survival during the long northern winters would have been impossible. Comparable evidence from earlier periods and regions further to the south is absent, apart from hints of connections with the submerged sea coast from occasional sea shells or other marine indicators present in hinterland sites.

It was long assumed that this florescence of maritime cultures in Mesolithic Europe, and comparable developments in other parts of the world at about the same time, was the result of population growth and new social, economic, and technological developments at that time. However, given the coincidence of this explosion of evidence with the period when eustatic sea levels stopped rising, an equally plausible hypothesis is that the pattern of evidence is just as likely to result from differential visibility and preservation. Comparable patterns of coastal settlement may well extend much further back in time to earlier periods of low sea level, but the evidence is now hidden from view. How far back in time we can trace these maritime patterns, and how much they differed from those visible in more recent millennia, is, of course, the key question, and it is one that can only be answered by underwater investigations, identification of submerged coastlines, and the search for underwater shoreline settlements.

A further topic of growing interest is the human impact of sea-level change. As more information has become available on the nature and extent of the submerged landscapes of the Last Glacial Period and the evidence of their exploitation, so attention has begun to focus on the social, economic, and demographic consequences of sea-level change, particularly sealevel rise and drowning of previously productive hunting grounds and wetland environments. At present, only limited investigations aimed at charting the socio-economic impact of sea-level rise are available and mostly only for the final stages of shoreline change in the Holocene (e.g., Harff and Lüth 2007, 2011). For the inundation of land exposed at earlier periods and lower sea levels, and especially for extensive areas such as the southern North Sea basin, there is, at present, insufficient evidence to go very much beyond speculation about the social consequences of long-term sea-level rise and the resulting and often-dramatic changes in ecological and geographical reconfiguration of coastal environments. However, simply to think about these consequences is to raise questions that should inform future research.

Perhaps the biggest challenge for the future is the purposeful and successful search for underwater prehistoric archaeological sites, especially further offshore and in deeper water. Mapping of the submerged landscape by remote sensing for features worth targeting with more focussed coring or diving, taking known finds dredged up by chance from the seabed as a starting point for more detailed exploration, use of predictive modelling such as Fischer's well-known fishing site model to identify site locations (Fischer 1993), closer engagement with offshore commercial and industrial operations, and development of acoustic techniques for identifying small finds and features typical of Stone Age cultures are just some of the strategies that are now being employed to further advance underwater investigations.

\section{References}

Ammerman AJ, Davis T (eds) (2013) Island archaeology and the origins of seafaring in the eastern Mediterranean. Proceedings of the Wenner-Gren Workshop held at Reggio Calabria on October 19-21, 2012. Part One. Eurasian Prehistory 10

Ammerman AJ, Davis T (eds) (2014) Island archaeology and the origins of seafaring in the eastern Mediterranean. Proceedings of the Wenner-Gren Workshop held at Reggio Calabria on October 19-21, 2012. Part Two. Eurasian Prehistory 11

Bailey GN (1983) Economic change in Late Pleistocene Cantabria. In: Bailey G (ed) Hunter-gatherer economy in prehistory. Cambridge University Press, Cambridge, pp 149-165

Bailey GN, Flemming N (2008) Archaeology of the continental shelf: marine resources, submerged landscapes and underwater archaeology. Quat Sci Rev 27:2153-2165

Bailey GN, Milner N (2002) Coastal hunters and gatherers and social evolution: marginal or central? Before 
Farming: The Archaeology of Old World HunterGatherers 3-4(1):1-15

Bailey GN, Harff J, Sakellariou D (eds) (2017) Under the sea: archaeology and palaeolandscapes of the continental shelf. Springer, Cham

Benjamin J, Bonsall C, Pickard C, Fischer A (eds) (2011) Submerged prehistory. Oxbow, Oxford

Benjamin J, Rovere A, Fontana A, Furlani S, Vacchi M, Inglis RH, Galili E, Antonioli F, Sivan D, Miko S, Mourtzas N, Felia I, Meredith-Williams M, GoodmanTchernov B, Kolaiti E, Anzidei M, Gehrels R (2017) Late quaternary sea-level changes and early human societies in the central and eastern Mediterranean Basin: an interdisciplinary review. Quat Int 449:29-57

Coles J (1984) The archaeology of wetlands. Edinburgh University Press, Edinburgh

Coles B (ed) (1992) The wetland revolution in prehistory, WARP occasional paper, vol 6. The Prehistoric Society and WARP (Wetland Archaeology Research Project), Exeter

Erlandson J (2001) The archaeology of aquatic adaptations: paradigms for a new millennium. J Archaeol Res 9:287-350

Evans AM, Flatman JC, Flemming NC (eds) (2014) Prehistoric archaeology on the continental shelf: a global review. Springer, New York

Fischer A (1993) Stone Age settlements in the Småland Bight: A theory tested by diving. Miljøministeriet, Skov- og Naturstyrelsen, København (In Danish and English)

Fischer A (ed) (1995) Man and sea in the mesolithic: Coastal settlement above and below present sea level. In: Proceedings of the International Symposium, Kalundborg, Denmark 1993, Oxbow monograph 53. Oxbow, Oxford

Fischer A (2004) Submerged stone age - Danish examples and North Sea potential. In: Flemming NC (ed) Submarine prehistoric archaeology of the North Sea. Research priorities and collaboration with industry, CBA Research Report, vol 141. Council for British Archaeology, York, pp 21-36

Fischer A, Pedersen L (eds) (2018) Oceans of archaeology, Jutland Archaeological Society Publications Vol. 101. Jutland Archaeological Society, Højbjerg

Flemming NC (ed) (2004) Submarine prehistoric archaeology of the North Sea. Research priorities and collaboration with industry. CBA Research Report, vol 141. Council for British Archaeology, York

Flemming N, Antonioli F (2017) Prehistoric archaeology, palaeontology, and climate change indicators from caves submerged by change of sea level. In: Campbell PB (ed) The archaeology of underwater caves. Highfield Press, Southampton, pp 23-38

Flemming NC, Cagatay MN, Chiocci FL, Galanidou N, Jöns H, Lericolais G, Missiaen T, Moore F, Rosentau A, Sakellariou D, Skar B, Stevenson A, Weerts H (2014) Land beneath the waves: submerged landscapes and sea level change. A joint geoscience-humanities strategy for European continental shelf prehistoric research. Chu NC, McDonough N (eds) position paper 21 of the European Marine Board, Ostend, Belgium

Flemming NC, Harff J, Moura D, Burgess A, Bailey GN (eds) (2017a) Submerged landscapes of the European continental shelf: quaternary paleoenvironments. Wiley, Chichester

Flemming NC, Harff J, Moura D (2017b) Non-cultural processes of site formation, preservation and destruction. In: Flemming NC, Harff J, Moura D, Burgess A, Bailey GN (eds) Submerged landscapes of the European continental shelf: quaternary paleoenvironments. Wiley, Chichester, pp 51-82

Galili E, Benjamin J, Herskovitz I, Weinstein-Evron M, Zohar I, Eshed V, Cvikel D, Melamed J, Kahanov Y, Bergeron J, Ruggles C, Ronen A, Kolska Horwitz L (2017) Atlit-yam: a unique 9000 year old prehistoric village submerged off the Carmel Coast, Israel - the SPLASHCOS Field School (2011). In: Bailey GN, Harff J, Sakellariou D (eds) Under the sea: archaeology and palaeolandscapes of the continental shelf. Springer, Cham, pp 85-102

Grant KM, Rohling EJ, Bar-Matthews M, Ayalon A, Medina-Elizalde M, Bronk Ramsey C, Satow C, Roberts AP (2012) Rapid coupling between ice volume and polar temperature over the past 150000 years. Nature 491:744-747

Grant KM, Rohling EJ, Ramsey CB, Cheng H, Edwards RL, Florindo F, Heslop D, Marra F, Roberts AP, Tamisiea ME, Williams F (2014) Sea-level variability over five glacial cycles. Nat Commun 5:1-9. https:// doi.org/10.1038/ncomms6076

Harff J, Lüth F (eds) (2007) SINCOS - sinking coasts: geosphere, ecosphere and anthroposphere of the Holocene southern Baltic Sea. Bericht der RömischGermanischen Kommission 88

Harff J, Lüth F (eds) (2011) SINCOS II - sinking coasts: geosphere, ecosphere and anthroposphere of the Holocene southern Baltic Sea. Bericht der RömischGermanischen Kommission 92

Harff J, Bailey GN, Lüth F (eds) (2016) Geology and archaeology: submerged landscapes of the continental shelf, Special publication 411. Geological Society, London

Harff J, Furmanczyk K, Von Storch H (eds) (2017a) Coastline changes of the Baltic Sea from south to east. Springer, Cham

Harff J, Flemming NC, Groh A, Hünicke B, Lericolais G, Meschede M, Rosentau A, Sakellariou D, Uścinowicz S, Zhang W, Zorita E (2017b) Sea level and climate. In: Flemming NC, Harff J, Moura D, Burgess A, Bailey GN (eds) Submerged landscapes of the European continental shelf: quaternary paleoenvironments. Wiley, Chichester, pp 11-49

Holmlund J, Nilsson B, Rönnby J (2017) Joint explorations of the sunken past: examples of maritime collaboration between industry and academia in the Baltic. In: Bailey GN, Harff J, Sakellariou D (eds) Under the sea: archaeology and palaeolandscapes of the continental shelf. Springer, Cham, pp 53-63 
Inglis RH, Bosworth W, Rasul NMA, Al-Saeedi AO, Bailey GN (2019) Investigating the palaeoshorelines and coastal archaeology of the southern Red Sea. In: Rasul NMA, Stewart ICF (eds) Geological setting, palaeoenvironment and archaeology of the Red Sea. Springer, Cham, pp 533-581

Lambeck K, Purcell A, Flemming N, Vita-Finzi C, Alsharekh A, Bailey GN (2011) Sea level and shoreline reconstructions for the Red Sea: isostatic and tectonic considerations and implications for hominin migration out of Africa. Quat Sci Rev 30(25-26):3542-3574

Lambeck K, Rouby H, Purcell A, Sun Y, Sambridge M (2014) Sea level and global ice volumes from the last glacial maximum to the Holocene. Proc Natl Acad Sci U S A 111(43):15296-15303. https://doi.org/10.1073/ pnas. 1411762111

Masters PM, Flemming NC (eds) (1983) Quaternary coastlines and marine archaeology. Academic, London

Menotti F, O'Sullivan A (eds) (2012) The Oxford handbook of wetland archaeology. Oxford University Press, Oxford

Missiaen T, Sakellariou D, Flemming NC (2017) Survey strategies and techniques in underwater geoarchaeological research: an overview with emphasis on prehistoric sites. In: Bailey GN, Harff J, Sakellariou D (eds) Under the sea: archaeology and palaeolandscapes of the continental shelf. Springer, Cham, pp 21-37

Moree JM, Sier MM (eds) (2015) Interdisciplinary research programme Maasvlakte 2, Rotterdam. BOOR, Rotterdam, pp 7-350

Shackleton NJ, Opdyke ND (1973) Oxygen isotope and paleomagnetic stratigraphy of Pacific core V28-238: oxygen isotope temperatures and ice volumes on a $10^{5}$ and $10^{6}$ year scale. Quat Res 3:39-55

Shackleton NJ, Imbrie J, Hall MA (1983) Oxygen and carbon isotope record of East Pacific core V19-30: implications for the formation of deep water in the late Pleistocene North Atlantic. Earth Planet Sci Lett 65:233-244

Shackleton JC, van Andel TH, Runnels CN (1984) Coastal paleogeography of the central and western Mediterranean during the last 125,000 years and its archaeological implications. J Field Archaeol 11:307-314
Siddall M, Rohling EJ, Almogi-Labin A, Hemleben C, Meischner D, Schmelzer I, Smeed DA (2003) Sealevel fluctuations during the last glacial cycle. Nature 423:853-858

Smith PJ (1997) Grahame Clark's new archaeology: the fenland research committee and Cambridge prehistory in the 1930s. Antiquity 71(271):11-30

Sturt F, Dix J, Grant MJ (2017) The history of industrylinked research in English waters: lessons for the future. In: Bailey GN, Harff J, Sakellariou D (eds) Under the sea: archaeology and palaeolandscapes of the continental shelf. Springer, Cham, pp 425-436

Sturt F, Flemming NC, Carabias D, Jöns H, Adams J (2018) The next frontiers in research on submerged prehistoric sites and landscapes on the continental shelf. Proceedings of the Geological Association. https://doi.org/10.1016/j.pgeola.2018.04.008

Tizzard L, Bicket AR, Benjamin J, de Loecker D (2014) A middle Palaeolithic site in the southern North Sea: investigating the archaeology and palaeogeography of area 240. J Quat Sci 29:698-710 https://doi. org/10.1002/jqs. 2743

Tizzard L, Bicket AR, de Loecker D (2015) Seabed prehistory: investigating the palaeogeography and Early Middle Palaeolithic archaeology in the southern North Sea. Wessex archaeology report 35. Wessex Archaeology, Salisbury

Uldum O, Benjamin J, McCarthy J, Feulner F, Lübke H (2017) The late mesolithic site of Falden, Denmark: results from underwater archaeological fieldwork and a strategy for capacity-building based on the SPLASHCOS mission. In: Bailey GN, Harff J, Sakellariou D (eds) Under the sea: archaeology and palaeolandscapes of the continental shelf. Springer, Cham, pp 65-84

Veth P, McDonald J, Ward I, O'Leary M, Beckett E, Benjamin J, Ulm S, Hacker J, Ross PR, Bailey G (2019) A strategy for assessing continuity in terrestrial and maritime landscapes from Murujuga (Dampier archipelago), north west shelf, Australia. Journal of Island and Coastal Archaeology. https://doi.org/10.10 80/15564894.2019.1572677

Wickham-Jones C (2018) Landscape beneath the waves: the archaeological investigation of underwater landscapes. Oxbow, Oxford

Open Access This chapter is licensed under the terms of the Creative Commons Attribution 4.0 International License (http://creativecommons.org/licenses/by/4.0/), which permits use, sharing, adaptation, distribution and reproduction in any medium or format, as long as you give appropriate credit to the original author(s) and the source, provide a link to the Creative Commons licence and indicate if changes were made.

The images or other third party material in this chapter are included in the chapter's Creative Commons licence, unless indicated otherwise in a credit line to the material. If material is not included in the chapter's Creative Commons licence and your intended use is not permitted by statutory regulation or exceeds the permitted use, you will need to obtain permission directly from the copyright holder.

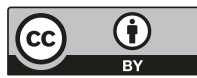

